\title{
RECORD OF THE MESO- AND NEOHOLOCENE PALAEOENVIRONMENTAL CHANGES IN THE JESIONOWA LANDSLIDE PEAT BOG (BESKID SĄDECKI MTS. POLISH OUTER CARPATHIANS)
}

\author{
WLODZIMIERZ MARGIELEWSKI ${ }^{1}$, PIOTR KOLACZEK ${ }^{2,3}$, ADAM MICHCZYŃSKI ${ }^{4}$, \\ ANDRZEJ OBIDOWICZ ${ }^{5}$ and ANNA PAZDUR ${ }^{4}$ \\ ${ }^{l}$ Institute of Nature Conservation, Polish Academy of Sciences, A. Mickiewicza Ave. 33, 31-120 Kraków, Poland \\ ${ }^{2}$ Department of Biogeography and Palaeoecology, Faculty of Geographical and Geological Science, Adam Mickiewicz University, \\ Dzięgielowa Str. 27, 61-680 Poznań, Poland \\ ${ }^{3}$ Department of Palaeobotany, Institute of Botany, Jagiellonian University, Lubicz Str. 46, 31-120 Kraków, Poland, \\ ${ }^{4}$ GADAM Centre of Excellence, Institute of Physics, Silesian University of Technology, Krzywoustego Str. 2, 44-100 Gliwice, Poland \\ ${ }^{5}$ Institute of Botany, Polish Academy of Sciences, Lubicz str. 46, 31-120 Kraków, Poland
}

Received 15 September 2010

Accepted 20 December 2010

\begin{abstract}
The paper presents an analysis of depositional sequences of landslide peat bog situated in the depressions developed within the landslide landforms Jesionowa in the Beskid Sądecki Mts. (Outer Carpathians). The peat bog, with depositional sequence $2.80 \mathrm{~m}$ long, started to form at the beginning of the Atlantic Phase ca. 6390-5910 cal BC. Palynological and lithological analyses as well as several (14) radiocarbon age determinations of different horizons in the sediments enabled the reconstruction of palaeoenvironmental changes during the Meso-and Neoholocene. The increase in climate humidity at the beginning of the Subboreal and Subatlantic Phases was observed as delivery of minerogenic material to the peat bog basin and formation of a mineral horizon and an illuvial level within the peat. The particularly intensive delivery of allochthonous material to the peat bog took place at the beginning of the Subboreal Phase and was the result of both significant humid climate and increased human impact (colonization of the Funnel Beaker Culture) in the landslide area. Similar influence of younger colonisations of landslide area (Przeworsk Culture and, later, Valachian colonisation) was also recorded within the deposits of peat bog (illuvial and mineral horizons) in the early Subatlantic Phase. Rejuvenation of the landslide zone and formation of the younger landslide were connected with the increase in climate humidity at the beginning of the Subboreal Phase. The peat bog deposits situated within this younger landslide, which are ca. $1.8 \mathrm{~m}$ thick, are significantly contaminated with mineral material.
\end{abstract}

Keywords: landslide peat bogs, palaeoenvironmental changes, Middle and Late Holocene, Human impact, Polish Flysch Carpathians.

\section{INTRODUCTION}

Peat bogs occurring within landslide depressions (called landslide peat bogs) are sensitive indicators of

Corresponding author: W. Margielewski

e-mail: margielewski@iop.krakow.pl palaeoenvironmental changes in mountains during the Late Glacial and the Holocene (Margielewski, 2006a; Obidowicz and Margielewski, 2008; Margielewski et al., $2010 a, b)$. An increase in the amount and frequency of extreme hydrometeorological events (downpours, longlasting rains), typical of humid climatic phases, generated 
intensive delivery of mineral material to the peat bog sediments. This material formed illuvial and minerogenic horizons within the peat bog sequences. Intensification of these phenomena was also caused by human activity, e.g. burnout of forests for agriculture (applied since the prehistoric time), intensive pasturing or cultivation (Starkel, 1988, 1989; Margielewski and Zernitskaya, 2003; Margielewski, 2006a).

Jesionowa site in the Beskid Sacdecki Mts. is one of the landslide peat bogs, within which the climatic changes during the Meso- and Neoholocene were recorded (Fig. 1). It is situated in the region of Polish Carpathians, within which the palaeoenvironmental changes have not been sufficiently investigated yet. The set of analyses of

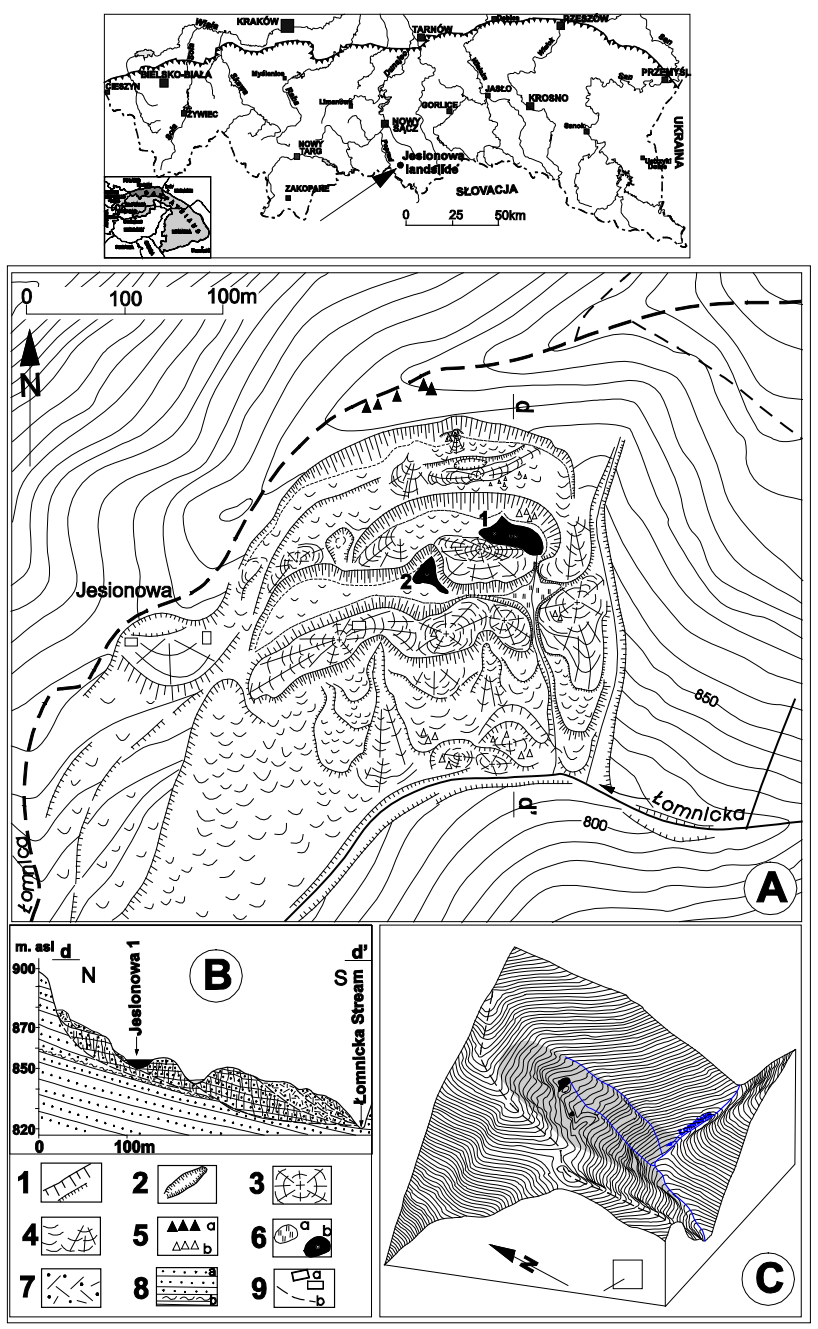

Fig. 1. The map of Jesionowa Landslide (A) with cross section (B) and orthogonal projection of hipsometry of landslide area in " $\mathrm{z}$ " value $(C)$. On draws, the position of analysed peat bogs was signed (as 1 and 2), according to description in the text. Legend symbols: 1 - scarps; 2 - trenches; 3 - landslide body; 4 - colluvial tongues; creeping; 5 - crags (a) and rock blocks and debris (b); 6 - swamps (a) and peat bogs (b) - with places of drilling; 7 - colluvial material (on cross section); 8 - bedrock and landslide body (on cross section): a - sandstones; $b$ - shales; 9 - buildings (a) and roads b). peat bog sediments (e.g. lithological and palynological analyses, radiocarbon dating) enabled to reconstruct palaeoclimatic changes as well as stages of prehistoric man activity in this region since the Atlantic Phase, when the landslide formed.

\section{STUDY AREA}

\section{Landslide description}

The Jesionowa landslide is situated in the eastern part of the Beskid Sądecki Mts. (Western Outer Carpathians; $\mathrm{N} 49^{\circ}$ 28,609'; E20 44,937', 850 m a.s.1.), which is built of flysch rock of the Krynica Subunit, Magura Unit (Nappe) (Chrząstowski et al., 1995). The landslide was formed on the slope of south-side subordinate ridge to the main ridge of the Jaworzyna Krynicka Range and it is situated in the upper segment of the Łomnicka stream valley. The landslide zone, developed in thick bedded Magura sandstones (forming the southern part of the Runek-Labowska Hala-Pisana Hala syncline), consists of a set of successive landslide structures. Landslides were successively formed by several mass movement generations stimulated by headward erosion (oldest stages) and lateral erosion of the Łomnicka stream (younger stages of mass movements). Older landforms are represented by two systems of circular landslide head scarps, 150-100 m long and ca. 10-20 m high (Fig. 1). During the subsequent mass movements a vast trench was formed in the lower part of the landslide zone (Margielewski, 1997a). Landslide represents complex, translational-rotational (displaced consequently to beds dip) type of gravitational displacements (see Dikau et al., 1996; Margielewski, 2006b).

During one of the older stages of gravitational displacements, in the upper part of the landslide zone, the depression ( $40 \mathrm{~m}$ long and $24 \mathrm{~m}$ wide) situated at the foot of one of the landslide heads a scarp was formed (Fig. 1A-1). This depression, whose maximum depth is ca. $2.8 \mathrm{~m}$, is filled with organic-minerogenic deposits of fen type peat bog (minerogenic mire) (Jesionowa 1 Fig. 2). The second peat bog (Jesionowa 2) occurs within the lower part of the landslide zone, at the bottom of the main trench (Fig. 1A-2).

\section{Recent vegetation}

An analysed fen is located in the beech-fir forest belt, close to the forest clearing. The site is partially surrounded by Fagus sylvatica woodland with a small admixture of Abies alba (Fig. 2). There are also Betula pendula patches and single specimens of Juniperus communis and Salix sp. in the close vicinity of the site. Wetter parts of the fen surface, especially along the stream, are overgrown by Scirpus sylvaticus, Eriophorum angustifolium, Carex flava, Typha latifolia, Juncus buffonius, J. articulatus, Caltha palustris and Equisetum uliginosus. Dryer sections of the mire are covered by plants typical of wet- 


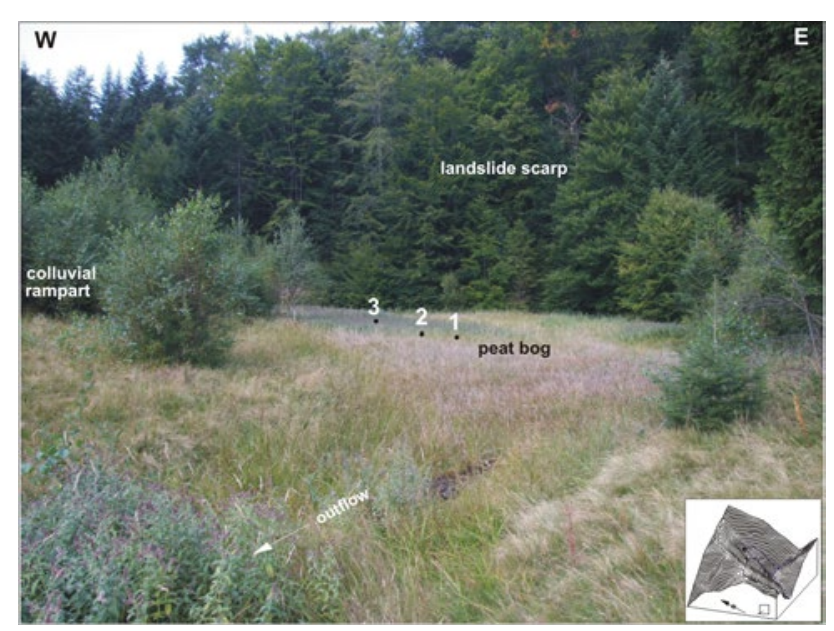

Fig. 2. View on main peat bog (Jesionowa 1), with location of logs (position of peat bog on orthogonal projection of hypsometry in " $\mathrm{z}$ " value).

ter parts combined with species, which are characteristic of the clearings used as mown meadows and/or pasturelands e.g. Briza media, Potentilla erecta, Luzula luzuloides, Mentha arvensis, Lychnis flos-cuculi, Lathyrus sp. and Alchemilla sp. The highest sectors of the fen (located close to the rocky slope) are overgrown by Epipactis palustris and Mentha longifolia which form a homogenous patch close to the place of the core collection. The additional element in the forest/fen ecotone is Urtica dioica which suggests higher nitrification of this part of the mire.

\section{MATERIALS AND METHODS}

Complex analyses (using also pollen and lithological analyses) were made on the core obtained from the deepest part of the fen.

Three cores were drilled and taken from the Jesionowa 1 peat bog using INSTORF sampler (Russian peat sampler), $6 \mathrm{~cm}$ and $8 \mathrm{~cm}$ in diameter. Loss on ignition analyses at a temperature $550^{\circ} \mathrm{C}$ based on sequential heating of the samples in a muffle furnace for $4 \mathrm{~h}$ (Heiri et al., 2001) were made for each $2.5 \mathrm{~cm}$ long section of the logs. Loss on ignition curves (percentage) were constructed for every $\log$ on the basis of these analyses (Fig. 3).

Peat sediments were analyzed by A. Obidowicz, who made also detailed identification of plant macrofossils.

Minerogenic sediments occurring within the peat bog were identified on the basis of Bouyoucos-Casagrande aerometric analyses modified by Prószyński (MycielskaDowgiałło and Rutkowski, 1995). Identification of these sediments was performed according to the Pettijohn classification (Pettijohn, 1975; Battaglia et al., 2003) using Wentworth's scale of grain size (Wentworth, 1922). The granulometric indexes: mean grain size $(\mathrm{Mz})$ and stand- ard deviation $\left(\sigma_{1}\right)$, were calculated for analysed mineral sediments (after Folk and Ward, 1957) (Fig. 4).

Conventional radiocarbon ages reported in the article were carried out using various materials in the Radiocarbon Laboratory of the Silesian University of Technology in Gliwice, Poland (laboratory code - Gd, GdS, GdC) and in the Radiocarbon Laboratory of the Ukrainian Academy of Sciences in Kiev (laboratory code - Ki) and in Radiocarbon Laboratory of AGH University of Sciences and Technology in Cracow (laboratory code - Kr). Calibration of the radiocarbon dates (expressed as cal yr BC/AD time intervals with probability $95 \%$ ) was carried out using the calibration data set IntCal09 (Reimer et al., 2009) and OxCal (version 4.1) calibration program (Bronk Ramsey, 2009). Generally, within the described peat bog 14 radiocarbon age determinations were carried out (Fig. 3; Table 1 and Table 2).

A complete palynological analysis was conducted for the deepest log of the main Jesionowa 1 peat bog (Fig. 5; Table 3). Drilling of the profile from Jesionowa 1 was performed in September 2009. The core was sampled at intervals of $5 \mathrm{~cm}$ and subsequently 39 subsamples $\left(1 \mathrm{~cm}^{3}\right.$ volume) were selected and prepared using modified Erdtman acetolysis (Erdtman, 1943) with an addition of hydrofluoric acid (Faegri and Iversen, 1989). To every sample a weighed Lycopodium tablet was added for further calculations of pollen concentration (Stockmarr, 1971). More than 500 arboreal pollen grains per sample were counted at $400 \times$ and $1000 \times$ magnification.

The pollen taxa were determined with the assistance of the modern pollen slide collection of the Władysław Szafer Institute of Botany, Polish Academy of Sciences, and special keys and atlases (Faegri and Iversen, 1989; Reille, 1992; Beug, 2004). The identification of nonpollen palynomorphs (NPPs) was done by comparison with photographs and descriptions available in the literature on NPPs (e.g. Van Geel, 1978; Van Geel et al., 1980, 2003 and 2007) (Fig. 6). The percentage values of individual taxa were calculated in the ratio to AP+NAP (arboreal pollen+non-arboreal pollen) excluding telmatophyte (with Cyperaceae) and limnophyte pollen as well as spores of Pteridophyta and Bryophyta and NPPs. The percentages of excluded taxa and NPPs were calculated in the ratio to $\mathrm{AP}+\mathrm{NAP}+$ taxon. Pollen diagrams were plotted using POLPAL software (Walanus and Nalepka, 1999; Nalepka and Walanus, 2003). Additionally, a dendrogram of the similarity between pollen spectra plotted using the ConSLink method was prepared using a program within POLPAL software.

In the second peat bog (Jesionowa 2) situated within the lower part of the landslide zone (Fig. 7) one borehole $\log$ was drilled with the peat sampler INSTORF. The sediments of this peat bog (mainly silts with organic admixture) have not been studied in detail at this stage of research. One radiocarbon date was carried out for the bottom part (tree trunk) of this peat bog (Table 2). 


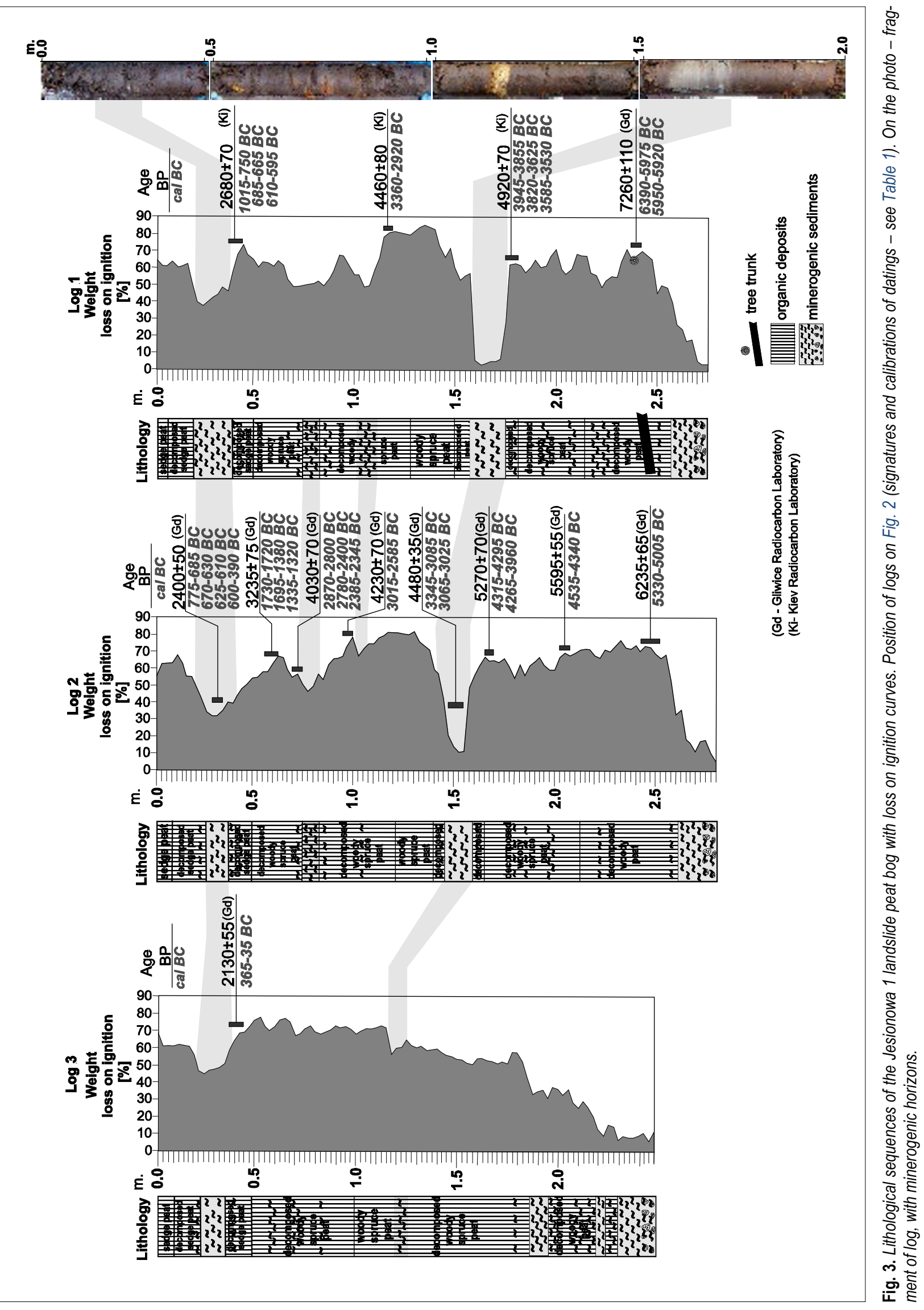


Table 1. Radiocarbon dates of the Jesionowa 1 landslide's peat bog (calibration using OxCal computer program v. 4.1 (Bronk-Ramsey, 2009$)$ on the basis of IntCal09 calibration curve (Reimer et al. 2009). The column "Calendar age $2 \sigma$ " presents results of calibration of radiocarbon dates, whereas the column "Modelled calendar age $2 \sigma$ " shows intervals connected with theses radiocarbon dates obtained as a result of age-depth model construction.

\begin{tabular}{|c|c|c|c|c|c|c|}
\hline $\begin{array}{l}\text { Depth } \\
\text { (cm) }\end{array}$ & Material & Lab. Code & $\begin{array}{l}\text { Age }{ }^{14} \mathrm{C} \\
\text { (yr } \mathrm{BP})\end{array}$ & $\begin{array}{c}\text { Calendar age } 2 \sigma \\
\text { (cal yr BC) }\end{array}$ & $\begin{array}{l}\text { Modelled calendar age } \\
2 \sigma \text { (cal yr BC) }\end{array}$ & Context of dating \\
\hline \multicolumn{7}{|l|}{$\log 1$} \\
\hline $38-45$ & Peat & Ki-13120 & $2680 \pm 70$ & $\begin{array}{c}1015-750(94 \%) \\
685-665(1 \%) \\
610-595(0.4 \%) \\
\end{array}$ & $\begin{array}{l}\text { not included in age-depth } \\
\text { model }\end{array}$ & $\begin{array}{l}\text { start of mineral horizon deposi- } \\
\text { tion }\end{array}$ \\
\hline $113-117$ & Peat & Ki-13121 & $4460 \pm 80$ & $3360-2920(95.4 \%)$ & $\begin{array}{l}\text { not included in age-depth } \\
\text { model }\end{array}$ & Illuvial horizon deposition \\
\hline $170-177$ & $\begin{array}{l}\text { Peat with wood } \\
\text { detritus }\end{array}$ & $d_{K i-13119}$ & $4920 \pm 70$ & $\begin{array}{c}3945-3855(9.9 \%) \\
3820-3625(81.3 \%) \\
3585-3530(4.2 \%)\end{array}$ & $\begin{array}{l}\text { not included in age-depth } \\
\text { model }\end{array}$ & Thick mineral horizon within peat \\
\hline $230-235$ & $\begin{array}{l}\text { Wood } \\
\text { (tree trunk) }\end{array}$ & Gd-4957 & $7260 \pm 110$ & $\begin{array}{c}6390-5975(93.5 \%) \\
5950-5920(1.9 \%)\end{array}$ & $\begin{array}{l}\text { not included in age-depth } \\
\text { model }\end{array}$ & Start of peat deposition \\
\hline \multicolumn{7}{|l|}{$\log 2$} \\
\hline $30-35$ & Peat with silt & GdC-327 & $2400 \pm 50$ & $\begin{array}{c}775-685(16 \%) \\
670-630(5.8 \%) \\
625-610(1.2 \%) \\
600-390(72.4 \%) \\
\end{array}$ & $\begin{array}{l}750-685(9.8 \%) \\
670-635(4.1 \%) \\
625-610(0.7 \%) \\
600-385(80.8 \%) \\
\end{array}$ & $\begin{array}{l}\text { start of mineral horizon deposi- } \\
\text { tion }\end{array}$ \\
\hline $56-63$ & Wood fragment & tGdS-1004 & $3235 \pm 75$ & $\begin{array}{c}1730-1720(0.3 \%) \\
1695-1380(94.4 \%) \\
1335-1320(0.7 \%) \\
\end{array}$ & $1745-1435(95.4 \%)$ & $\begin{array}{l}\text { Start of gradual delivery of } \\
\text { mineral material to peat bog }\end{array}$ \\
\hline $70-75$ & peat & GdS-1007 & $4030 \pm 70$ & $\begin{array}{c}2870-2800(9.9 \%) \\
2780-2400(83.2 \%) \\
2385-2345(2.3 \%) \\
\end{array}$ & $\begin{array}{l}2630-2285(95.1 \%) \\
2250-2240(0.3 \%)\end{array}$ & $\begin{array}{l}\text { End of mineral horizon sedimen- } \\
\text { tation }\end{array}$ \\
\hline $95-100$ & peat & GdS-1005 & $4230 \pm 70$ & $3015-2585(95.4 \%)$ & $3020-2695(95.4 \%)$ & $\begin{array}{l}\text { Start of gradual delivery of } \\
\text { mineral material to peat bog }\end{array}$ \\
\hline $148-155$ & Wood fragment & tGdS-990 & $4480 \pm 35$ & $\begin{array}{c}3345-3085(89.2 \%) \\
3065-3025(6.2 \%) \\
\end{array}$ & $\begin{array}{l}3345-3080(86.7 \%) \\
3070-3025(6.2 \%) \\
\end{array}$ & Thick mineral horizon deposition \\
\hline $165-170$ & peat & GdC-357 & $5270 \pm 70$ & $\begin{array}{c}4315-4295(1.5 \%) \\
4265-3960(93.9 \%)\end{array}$ & $\begin{array}{l}4215-3945(93.9 \%) \\
3855-3815(1.5 \%) \\
\end{array}$ & $\begin{array}{l}\text { Start of thick mineral horizon } \\
\text { deposition }\end{array}$ \\
\hline $202.5-210$ & Peat & GdC-325 & $5595 \pm 55$ & $4535-4340(95.4 \%)$ & $4610-4380(95.4 \%)$ & $\begin{array}{l}\text { Series of weak delivery of miner- } \\
\text { al material to peat bog }\end{array}$ \\
\hline $242.5-252.5$ & $\begin{array}{l}\text { Peat with wood } \\
\text { detritus }\end{array}$ & d GdS-1008 & $6235 \pm 65$ & $5330-5005(95.4 \%)$ & $5300-4955(95.4 \%)$ & $\begin{array}{l}\text { Start of peat deposition / for- } \\
\text { mation of landslide depression }\end{array}$ \\
\hline \multicolumn{7}{|c|}{$\log 3$} \\
\hline $37.5-45$ & Peat with wood & d GdC-359 & $2130 \pm 55$ & $365-35(95.4 \%)$ & $\begin{array}{l}\text { not included in age-depth } \\
\text { model }\end{array}$ & $\begin{array}{l}\text { Start of mineral horizon sedimen- } \\
\text { tation }\end{array}$ \\
\hline
\end{tabular}

Table 2. Radiocarbon dates of the Jesionowa 2 landslide's peat bog (calibration using OxCal computer program v. 4.1 (Bronk-Ramsey, 2009$)$ on the base of IntCal09 calibration curve (Reimer et al. 2009).

\begin{tabular}{|c|c|c|c|c|c|}
\hline $\begin{array}{l}\text { Depth } \\
\text { (cm) }\end{array}$ & Material & Lab. Code & $\begin{array}{l}\text { Age }{ }^{14} \mathrm{C} \\
\text { (yrs BP) }\end{array}$ & $\begin{array}{l}\text { Calendar age } 2 \sigma \\
\text { (cal yr BC) }\end{array}$ & Context of datings \\
\hline \multicolumn{6}{|l|}{$\log 1$} \\
\hline 200 & $\begin{array}{l}\text { Wood } \\
\text { (tree trunk) }\end{array}$ & Kr-150 & $4790 \pm 90$ & $\begin{array}{c}3765-3725(1.8 \%) \\
3715-3365(93.5 \%)\end{array}$ & Formation of landslide depression \\
\hline
\end{tabular}




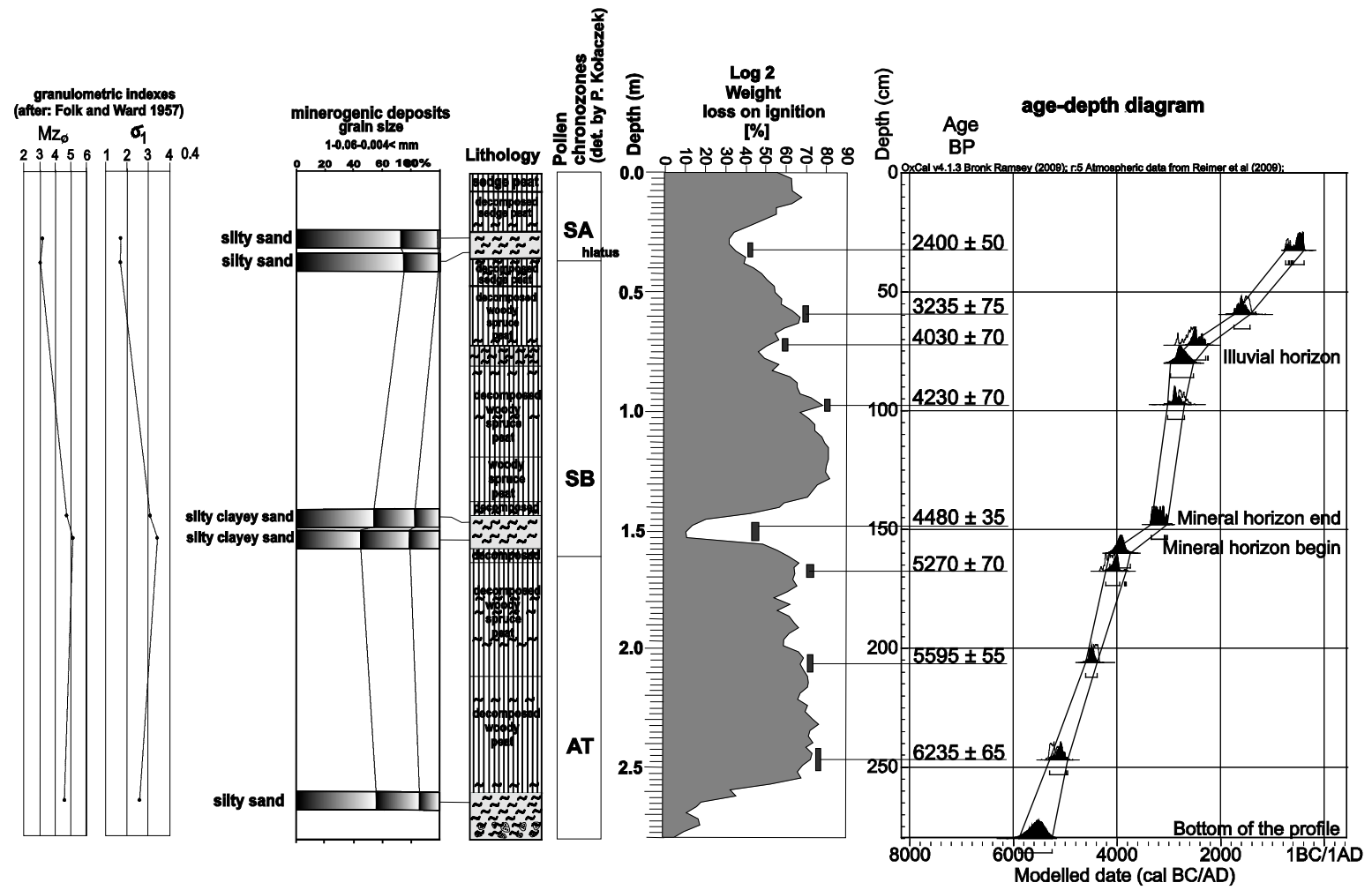

Fig. 4. Lithostratigraphic sequence of the central log of Jesionowa 1 peat bog (see log 2 on Fig. 3) and age-depth model of deposits. Log showing types of peat and grain size (areometry) of minerogenic sediments, with granulometric sequences and loss on ignition curve. Explanation of symbols is given in Fig. 3.

Table 3. Description of Local Pollen Assemblages Zones of the Jesionowa 1 peat bog (det. by P. Kołaczek).

\begin{tabular}{|c|c|c|c|}
\hline L PAZ & $\begin{array}{l}\text { Depth } \\
(\mathrm{cm})\end{array}$ & L PAZ description & $\begin{array}{l}\text { Top boundary } \\
\text { description }\end{array}$ \\
\hline Jes1-1. Corylus & $280-205$ & $\begin{array}{l}\text { Domination of Corylus avellana (21-55.5\%), the highest values of Ulmus (15\%), Tilia cordata t. } \\
\text { and Acer. Constant occurrence of limno- and telmatophytes with maximum of Type } 315 \text { Spiro- } \\
\text { gyra t. (2\%), continuous curve of Type } 44 \text { Ustulina cf. deusta (max. } 4.5 \% \text { ) and Type } 112 \\
\text { Cercophora t. }\end{array}$ & \multirow{3}{*}{$\begin{array}{l}\text { Decrease in Cory- } \\
\text { lus avellana, } \\
\text { increase in Picea } \\
\text { abies }\end{array}$} \\
\hline \begin{tabular}{|l|l|l|l} 
a & Tilia \\
\end{tabular} & $280-234.5$ & Maximum of Tilia cordata t. (14.5\%) and Ulmus, domination of Corylus avellana. & \\
\hline \begin{tabular}{|l|l|}
$b$ & Corylus \\
\end{tabular} & $234.5-205$ & Domination of Corylus avellana, decrease in Tilia cordata & \\
\hline Jes1-2. Picea & $205-70$ & Domination of Picea abies (max. 72.5\%), sharp decrease in Corylus avellana curve. & \multirow{4}{*}{$\begin{array}{l}\text { Increase in Abies } \\
\text { alba and Filicales } \\
\text { monolete }\end{array}$} \\
\hline a Picea & $234.5-174.5$ & Rapid increase in Picea abies curve, maximum and decrease in Cyperaceae. & \\
\hline b Fraxinus & $174.5-147.5$ & $\begin{array}{l}\text { Fall in Picea abies, clear rise in Fraxinus excelsior curve (max. } 31 \%) \text {, slight increase in Corylus } \\
\text { avellana; single findings of Cerealia t. (at the depths } 145 \text { and } 150 \mathrm{~cm} \text { ); appearance of limno- } \\
\text { and telmatophytes pollen with algae in the upper part of the subzone. }\end{array}$ & \\
\hline c Picea & $147.5-70$ & $\begin{array}{l}\text { Stable increase in Picea abies values to its maximum in profile }(72.5 \%) \text {, decrease in Fraxinus } \\
\text { excelsior and Corylus avellana. }\end{array}$ & \\
\hline $\begin{array}{l}\text { Jes1-3. Picea- } \\
\text { Abies-Filicales }\end{array}$ & $70-32.5$ & $\begin{array}{l}\text { Although slight decline in Picea abies values still dominates, visible rise in Abies alba curve } \\
\text { (max. 20.5\%), constant increase in Pinus sylvestris t., rise in Fagus sylvatica and Carpinus } \\
\text { betulus; The highest values of Filicales monolete in profile (max. 53\%). }\end{array}$ & $\begin{array}{l}\text { Sharp decrease in } \\
\text { Picea abies; in- } \\
\text { crease in NAP }\end{array}$ \\
\hline Jes1-4. NAP-Pinus & $32.5-1$ & 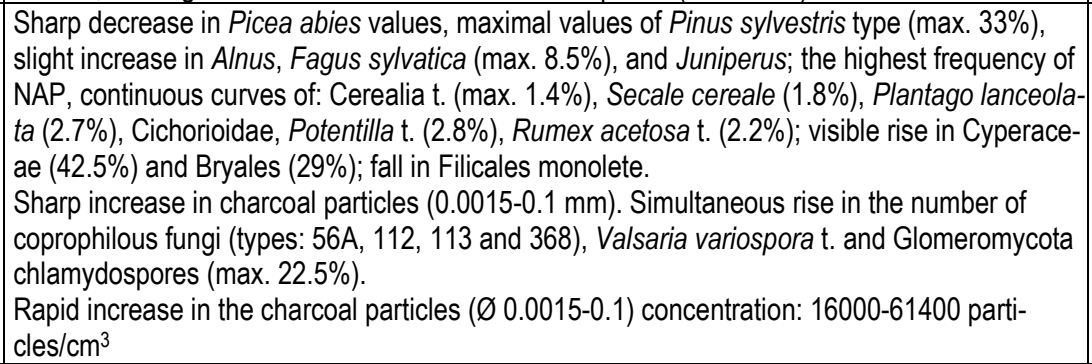 & \\
\hline
\end{tabular}




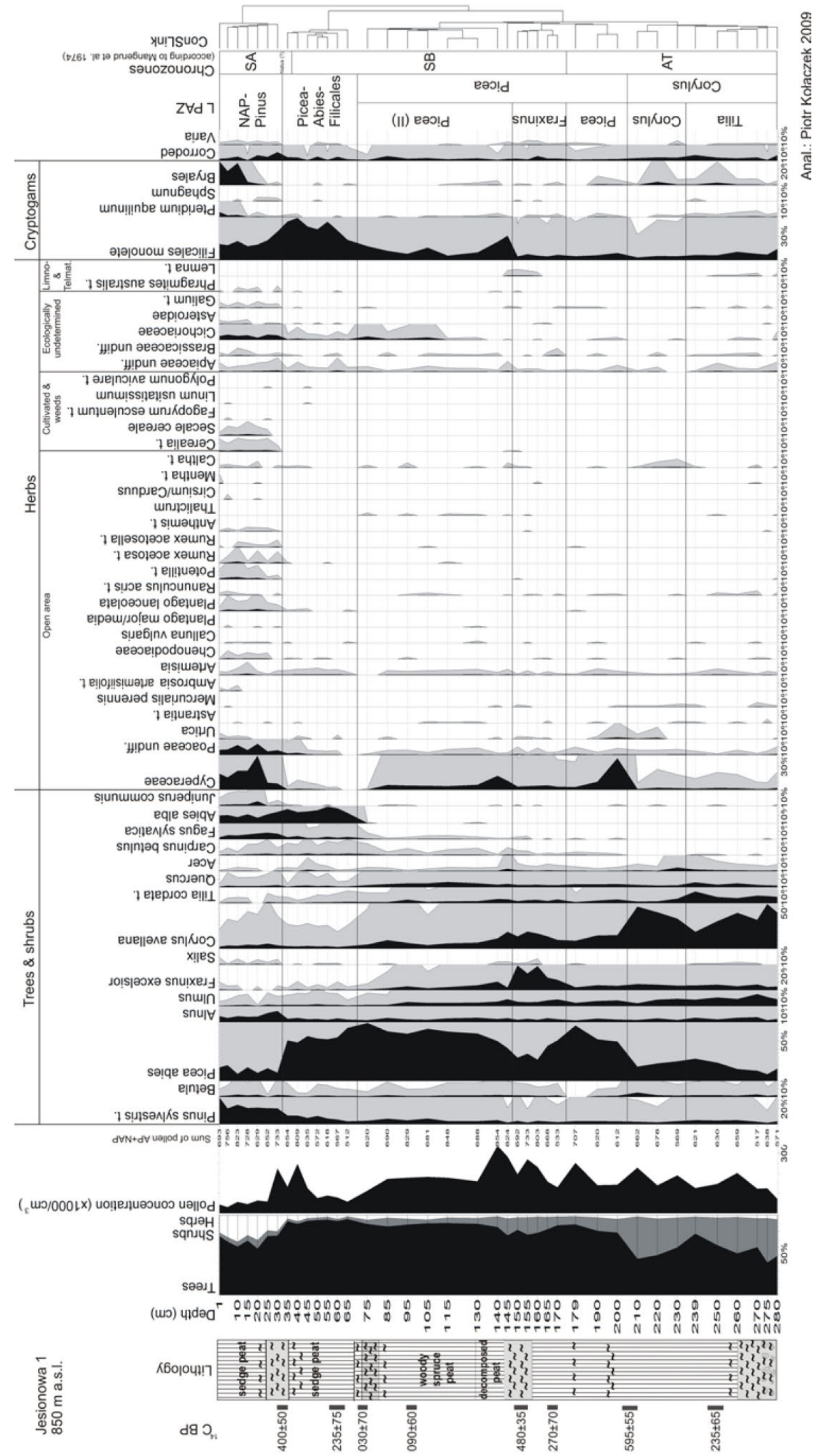

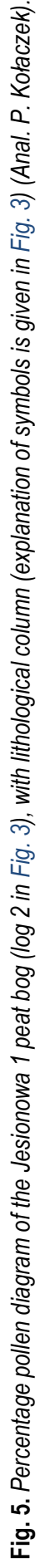




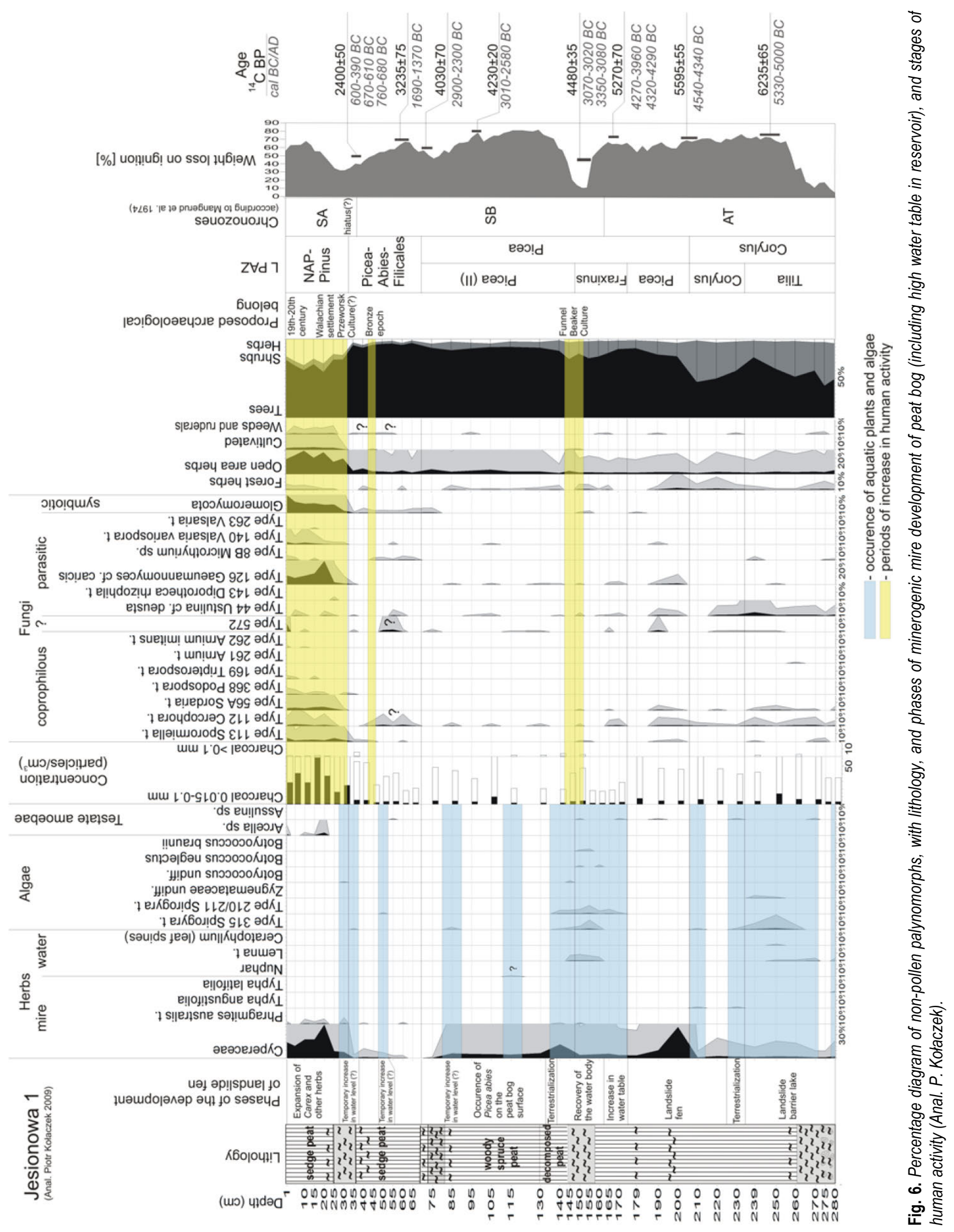




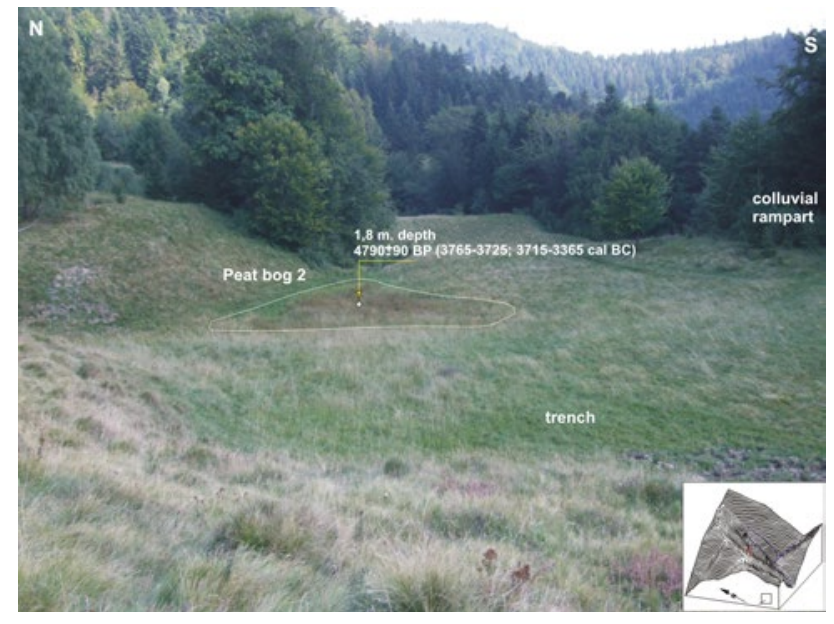

Fig. 7. A view of Jesionowa 2 landslide peat bog, with place of drilling.

\section{SEQUENCES OF DEPOSITS}

\section{Jesionowa 1}

At the bottom part of the peat bog, within the interval 2.80-2.65 m, mineral sediment (coating the bottom of the depositional basin) occurs. The sediment is represented by silty sand $(\mathrm{Mz}=4.6 \varphi)$, which is poorly sorted $\left(\sigma_{1}=2.6\right)$ and high content of sand fraction in it is typical of highenergy sediment (sensu Kotarba, 1996), deposited due to intensive delivery of allochthonous material to the basin. Upon this sand, in the interval $2.65-1.70 \mathrm{~m}$, highly decomposed woody peat occurs. In the lower part of the sequence peat contains numerous wood fragments of Salix sp. and rare partings of Picea abies. Above the depth of $2.1 \mathrm{~m}$, woody spruce peat occurs with predominating spruce fragments $(>40 \%)$ and in place with an admixture of Ericaceae and Salix sp. partings. It is covered by thin $(7 \mathrm{~cm})$ horizon of strongly decomposed peat (Fig. 3). The beginning of the peat accumulation was dated by radiocarbon at $6235 \pm 65 \mathrm{BP}(5330-5005 \mathrm{cal} \mathrm{BC})$. The radiocarbon date obtained from the bottom of peat layer in the second $\log$ is older: $7260 \pm 110$ BP (6390$5975 ; 5950-5920 \mathrm{cal} \mathrm{BP})$. This is caused by the fact that in the latter case a fragment of tree trunk thrown into the basin during the landslide formation (and lying at the bottom of depositional sequence) was dated. Therefore this date reflects the moment of the depression and landslide formation in the early stage of the Atlantic Phase (Margielewski, 1997a). It also indicates that, the peat accumulation began slightly later (Fig. 3, logs: 1 and 2). The palynological analysis confirms that, the lowermost peat layer within the sequence was accumulated during the Atlantic Phase (Figs. 4 and 5). At its top, the slight and cyclic supply of the mineral material to the peat bog is marked on the loss on ignition curves.

Upon woody peat, in the interval 1.6-1.4 m, horizon of homogenous mineral deposits is marked (in various logs the losses on ignition range 5-10\%). It is represented by silty clayey sand $\left(\mathrm{M}_{\mathrm{z}}=4.7-5.1 \varphi\right)$ (Fig. $\left.3, \operatorname{logs} 1-2\right)$ which is very poorly sorted $\left(\sigma_{1}=3.1-3.4\right)$ with high content of sand fraction related to the high dynamics of the allochthonous material delivery to the basin. The radiocarbon dating of the bottom of this horizon $(5270 \pm 70 \mathrm{BP}$ and $4920 \pm 70 \mathrm{BP}$ - see Table 1) indicate, that it was accumulated at the beginning of the Subboreal Phase.

Above the mineral horizon $5 \mathrm{~cm}$ thick strongly decomposed peat occurs. It is overlain by a layer of woody peat, reaching the depth of $0.50 \mathrm{~m}$. The lower section of this layer $(1.35-1.20 \mathrm{~m})$ is represented by slightly decomposed woody spruce peat which contains up to $80 \%$ wood of Picea abies. Within the higher section of the layer (1.20-0.65 m) spruce peat is strongly decomposed (humification degree $>45 \%$ ) and contains up to $40 \%$ wood of Picea abies as well as fragments of Sphagnum S. Cuspidata, Sphagnum sp., Thelypteris palustris and, in places, wood partings of Salix sp. Within the uppermost section $(0.65-0.50 \mathrm{~m})$ woody peat is strongly decomposed and contains detritus of Carex sp. and wood of Larix sp., Alnus sp., Picea abies.

Within the layer of woody peat, an illuvial horizon is marked in the loss on ignition curve by gradual decrease in losses from $80 \%$ to $40 \%$ (Fig. 3, $\log 2$ ). Its bottom was dated at $4230 \pm 70 \mathrm{BP}(3015-2585 \mathrm{cal} \mathrm{BC})$, while top at $4030 \pm 70$ BP (approximately $2870-2345$ cal BC) (in the other log, the date of the bottom of analogous horizon is older: $4460 \pm 80$ BP (3360-2920 cal BC).

The top part of peat (the last $0.50 \mathrm{~m}$ of the sequence) is formed of strongly decomposed sedge peat, covered by a thin layer of sedge peat which did not undergo humification. It contains up to $60 \%$ fragments of Carex sp., as well as some detritus of Equisetum palustre. Within this layer, an illuvial horizon occurs, that contains in its middle part a mineral horizon ca. $0.15 \mathrm{~m}$ thick (Fig. 3). The granulometric composition of this mineral sediment (analysis of fresh, unheated sample as well as a sample after heating to the temperature of $550^{\circ} \mathrm{C}$ ) indicates that the minerogenic horizon is formed of silty sand $\left(\mathrm{M}_{\mathrm{z}}=3.1\right.$ $3.0 \varphi$ ), typical of high-energy sediments. In various logs the supply of allochtonous material to the basin was dated at $2400 \pm 50 \mathrm{BP}$ (approx. 775-390 cal BC); $2680 \pm 70 \mathrm{BP}$ (approx. 1015-595 cal BC - see Table 1) and 2130 \pm 55 BP (365-35 cal BC). The early Subatlantic age of this illuvial horizon is indicated also by palynological analysis which confirms the occurrence of hiatus in its bottom part (Figs. 4 and 5).

\section{Jesionowa 2}

At the bottom of the extensive trench connected with the youngest stage of the landslide zone rejuvenation a small (ca. $40 \mathrm{~m}$ in diameter) depression filled with organic sediments $1.8 \mathrm{~m}$ thick is situated. Within the lowermost part of its sequence (peaty silt) a tree trunk was found. The wood sample was dated by radiocarbon at 4790 190 BP (3765-3725; 3715-3365 cal BC) (Margielewski, 1997a). 


\section{PALYNOLOGICAL ANALYSIS}

The pollen diagram was divided into local pollen assemblage zones (L PAZ) according to Birks $(1979,1986)$ and Janczyk-Kopikowa (1987) (Fig. 5). The diagram was also divided into chronozones proposed by Mangerud et al. (1974). Numerical analysis ConSLink confirmed spectra grouping into L PAZs, as well as it confirmed division of some of them into subzones. The results of palynological analysis are presented in Table 3, Figs. 5 and 6. Time intervals of the pollen assemblage zones were estimated using the age-depth model discussed in a later chapter.

\section{Local vegetation development and human activity}

\section{Jes1-1. L PAZ Corylus. (from approx. 5900-5300 cal $B C$ to $4600-4365$ cal BC)}

Hazel (Corylus avellana) thickets - a dominating community in the vicinity of the site - coexisted with patches of spruce forest. Single alder (Alnus) and ash (Fraxinus excelsior) trees surrounded the water body which originated in the landslide depression. The lower part of the mountains was overgrown by mixed forest with elm (Ulmus sp.), maple (Acer sp.) and lime (Tilia cordata). The last taxon occurrence declined in the Jes1$1 \mathrm{~b}$ subzone. Domination of hazel and broadleaved trees during the climate optimum is stressed by the highest frequency of Ustulina cf. deusta spores - parasitic/saprophytic fungus whose optimal temperature for ascospores germination is $25-30^{\circ} \mathrm{C}$ (Van Geel and Andersen, 1988). The surface of the landslide barrier lake was overgrown by Lemnaceae (Lemna t.). Its subsequent shallowing favoured algae blooming which is demonstrated by the increase in Spirogyra t. (type 315) and the occurrence of other unidentified zygnemataceous zygospores (Fig. 6).

\section{Jes1-2. L PAZ Picea. (from 4600-4365 cal BC to 2520- 2045 cal BC)}

This zone is divided into 3 subzones. Cooler and wetter climatic conditions in the Jes1-2a subzone favoured the expansion of spruce (Picea abies) which prevented hazel from growing in the shady understorey and replaced it from most of its habitats. This phenomenon started $\sim 4540-4340$ cal BC. In the Jes1-2a subzone the landslide barrier lake developed into fen overgrown mostly by Cyperaceae, but temporary higher water level on its surface was demonstrated by single findings of Spirogyra zygospores.

In the Jes1-2b subzone higher humidity attributed to the Atlantic/Subboreal Phases transition caused the expansion of ash (Fraxinus excelsior) in the vicinity of the site. This species can grow well under conditions of high surface moisture and high groundwater level and is tolerant of seasonal inundation and floods (Faliński and Pawlaczyk, 1995). Low competitiveness of ash, which is compensated by the production of large quantities of seedlings capable of rapid growth (Ellenberg, 1996), as well as the fact of the relatively low pollen productivity of this taxon (comp. Pohl, 1937 following Tobolski and Nalepka, 2004) suggest considerable disappearance of spruce (more competitive taxon) in the closest vicinity of the site. What is more, the percentage values of ash pollen significantly (up to $\sim 10$ times) exceed its patterns presented in the isopollen maps (comp. Tobolski and Nalepka, 2004). The constant occurrence of Lemnaceae, as well as the presence of Spirogyra zygospores (type 210/211 and 315) point to the increase in water level and recovery of the water body. This filamentous algae genus is related to shallow lakes (Kadłubowska, 1972).

The Jes1-2c subzone presents the subsequent expansion of spruce, which rapidly replaced ash from most of its sites. Lowering of the water level caused fen regeneration and enabled the expansion of spruce on its surface. On the boundary between the Jes- $1 \mathrm{~b}$ and $\mathrm{c}$ subzones single Cerealia t. pollen grains were found. This fact was probably the effect of the agricultural activity of the people of Funnel Beaker Culture, whose occurrence in the Western Carpathian Mountains is dated to 3700-1900 BC (Valde-Nowak, 1988 and 2001; Kadrow, 2001). This phenomenon was not correlated with a visible decrease in AP (arboreal pollen) values and increase in the occurrence of synanthropic taxa, so then it might have been the effect of distant transport from lower parts of the mountains and/or human activity in the surrounding of mire was not significant.

Jes1-3. L PAZ Picea-Abies-Filicales (from 2520-2045 cal BC to approx. 760-390 cal BC)

Expanding fir (Abies alba) and beech (Fagus sylvati$c a$ ), which began replacing spruce from some of its habitats, started to form beech forest typical for lower mountain forest belt. Ferns dominated in those woodlands groundcover. In lower parts of the mountains hornbeam (Carpinus betulus) slightly broadened its range. The higher values of coprophilous fungi spores from the Cercophora t. might suggest temporal grazing activities, whereas finding a pollen grain of Linum usitatissimum with the simultaneous presence of Polygonum aviculare at the depth of $45 \mathrm{~cm}$ suggests agriculture activity in the vicinity of the site between 1690 and $390 \mathrm{BC}$. These findings might be traces of the settlements of people of the Lusatian Culture (the Bronze epoch and early Iron epoch) spread in the Carpathians between 1400-300 BC (Kozłowski and Kaczanowski, 1998; Valde-Nowak, 2000). The temporal higher water level on its surface was demonstrated by single findings of Spirogyra zygospores (Fig. 6). 


\section{Jes1-4. L PAZ (from approx. 760-390 cal BC to 2000 cal $A D)$}

This zone reflects visible deforestation where previously dominant spruce was replaced by fir and beech in most of the sites (development of lower mountain forest). An increase in Pinus sylvestris t. values was probably affected by distant transport. Open area communities were exploited as pastures. This is visible in the rise in Poaceae undiff., Potentilla t., Rumex acetosa t. pollen and coprophilous fungi (Cercophora t., Sordaria t., Sporormiella t. and Podospora t.) values (Figs. 5 and 6). Those areas might have been also used as mown meadows and this contributed to the spread of Plantago lanceolata. In lower parts of the mountains (may be also in the vicinity) cultivation of cereals (Cerealia t. and Secale cereale) supplemented by Fagopyrum and Linum usitatissimum was developed (Fig. 5). High amounts of charcoal particles in size between 0.0015 and $0.1 \mathrm{~mm}$ suggest fires whereas low frequency of particles above $0.1 \mathrm{~mm}$ related to local fires, according to Toney and Anderson (2006) points to a distant transport of those particles. However, the expansion of Pteridium aquilinum may suggest the occurrence of local fires because soil acidifcation after fires favours the germination of its spores, so that young plants appear in a great number on soils fertilized by ash (Page, 1986; Oberdorfer, 1990). These changes may have been triggered by the peoples of the Przeworsk Culture (ca. 200 BC-450 AD) (see: Madyda-Legutko, 1996; Kozłowski and Kaczanowski, 1998), and was continued later, during Slavonic settlements spread since $6^{\text {th }}$ Century, and Valachian colonization of the Carpathians who migrated from the south in the $15^{\text {th }}-16^{\text {th }}$ century (Godłowski and Kozłowski, 1979; Pietrzak, 2002). Even though radiocarbon data would suggest continuous settlement from the beginning of the Subatlantic Period and pollen spectra suggest high level of deforestation since then, archaeological data does not confirm this fact and point the demographical crisis during the Migration Period, which usually should have been recorded in pollen spectra. The continuous occurrence of charcoal particles in the Subatlantic deposits was rather caused by fire made by Valachian settlers or there is sediment discontinuity between the period of the Przeworsk Culture activity and the period of the Valachian domination in the region. Both groups of people used fire to obtain new area for pastureland. Taking into consideration the Ambrosia artemisiifolia type appearance, which according to Makra et al. (2005) reflects the expansion of the American species of ragweed in the southern Europe in the $19^{\text {th }}$ century, the age of the uppermost $10-15 \mathrm{~cm}$ of this zone may be approximated to the $19^{\text {th }}-20^{\text {th }}$ century.

Species from the Cyperaceae family along with other herb taxa spread on the fen surface in this zone. These processes might be correlated with the occurrence of chlamydospores of symbiotic fungi from the Glomeromycota class. Some authors link their presence in the lacustrine sediments with intensification of erosion (Van Geel, 2001).

\section{AGE-DEPTH MODEL FOR JESIONOWA 1 BASED ON RADIOCARBON DATES}

Table 1 presents radiocarbon dates of samples collected from the Jesionowa 1 landslide's peat bog. A total number of dated samples is 13 , but they were taken from three separate peat profiles (see Fig. 3) called Log 1 (4 samples), Log 2 (8 samples) and Log 3 (1 sample). Then, in order to avoid any problems connected with a correlation of depths in different profiles, it was decided to construct an age-depth model for the peat bog based only on radiocarbon dates from $\log 2$. The age-depth model has been constructed using OxCal 4.1 function $P$ Sequence, which is one of the new functions of the OxCal program dedicated to an age-depth model building (Bronk Ramsey, 2008). The model calculated by this function assumes that a deposition rate was not constant, but it was undergoing random fluctuations. The use of $P \_$Sequence function requires estimation of the $k$ parameter, which describes a magnitude of the fluctuations from a constant deposition rate. At the age-depth model for Jesionowa 1 we assumed that the $\mathrm{k}$ parameter is equal to $1 \mathrm{~cm}^{-1}$ which is a mean value from a range of reasonable values of $k$ parameter according to Bronk Ramsey suggestions (Bronk Ramsey, 2008; posts on oxcal@googlegroups.com). Such value of $k$ parameter was also suggested by results of tests made by one of the authors (Hajdas and Michczyński, 2010; Michczyński, 2011).

As it was described above, there are three distinct mineral or illuvial horizons in the peat profile Jesionowa 1 (Fig. 3). They are connected with phases, when climate humidity increases and extreme hydrometeorological events are much more frequent. Therefore in the agedepth model for Jesionowa 1 we made an assumption that sudden and significant changes of the deposition rate might have taken place for these phases. In order to include this assumption in our age-depth model we use Boundary command of OxCal 4.1 program (Bronk Ramsey, 2008). Because the uppermost sample included in the age-depth model (GdC-327, depth $30-35 \mathrm{~cm}$ ) is located a bit below the upper mineral (illuvial) horizon, only two of three horizons are taken into consideration. In the future we are going to supplement our age-depth model by including additional radiocarbon dates of a sample (or samples) collected from the uppermost part of the peat profile. More details concerning the construction of the Jesionowa 1 age-depth model are presented in another publication (Michczyński, 2011).

The results of the age-depth model of Jesionowa 1 peat profile are presented in Fig. 4 (right side of the graph - the age-depth relation) and Table $1(95.4 \%-2 \sigma-$ confidence intervals of radiocarbon dates included in the model). An overall agreement index of the model 
amounts to $71.8 \%$, which is more than a suggested critical value $(60 \%)$, which allows to accept a model as reliable. It means that the assumptions of our model are in concordance with radiocarbon dates. It is clearly visible, that there are significant changes of a deposition rate connected with phases when intensive delivery of minerogenic material was observed (see Fig. 4). At the lower part of the profile, which was deposited at the Atlantic Phase, the deposition rate is equal ca. $0.73 \mathrm{~mm} /$ year. At a depth of about $150 \mathrm{~cm}$ (beginning of the Subboreal Phase), above the mineral horizon, the deposition rate increases substantially and reaches a value of ca. $1.5 \mathrm{~mm} /$ year. This deposition rate remains unchanged till the middle of the Subboreal Phase and decreases above the next larger delivery of mineral material which appears at the depth of about $80 \mathrm{~cm}$. Beyond this illuvial horizon the deposition rate is equal to only about $0.21 \mathrm{~mm} / \mathrm{year}$. During the Subboreal Phase we have observed two different rates of the deposition process - very high rate in the early Subboreal and low rate in the middle and late Subboreal.

The age-depth model by its extension to a depth related to the bottom of the investigated peat profile allows us to estimate an age of the formation of landslide depression (see Fig. 4). It gives us $95 \%(2 \sigma)$ confidence interval, which comes to $5890-5250$ cal BC. This interval is still younger than the age of the wood sample from the Log 1 peat profile (Gd-4957: 6390-5975 cal BC and 5950-5920 cal BC), but is close to it. This result supports our explanation of difference between dates from bottom parts of $\log 1$ and $\log 2$ (see Table 1 ).

\section{DEPOSITIONAL RESPONSE ON PALAEOEN- VIRONMENTAL CHANGES}

The radiocarbon dating as well as the palynological analysis indicate that the landslide depression was formed in the early stage of the Atlantic Phase. The tree trunk buried in the sediments coating the bottom of the depression dated at approximately 6390-5920 cal BC (Gd-4957) was undoubtedly connected with the destruction of forest by the landslide transforming slope of the Lomnicka stream valley (Margielewski, 1997b). The development of the landslide was related to the increase in climate humidity. The intensification of hydrometeorological phenomena generated formation of numerous landslides in the area of Polish Carpathians (Margielewski, 2006a). Common climate changes during this time (cooling and humidity increase) in Europe, caused a growth of the fluvial activity of Upper Vistula River (Starkel et al., 1996), as well as a rise of water table in the subalpine lakes (Magny, 1993 and 2004). The climate cooling caused advances of Alpine glaciers (Frosnitz glacial advance - Bortenschlager, 1982) (Fig. 8). Intensification of rains (downpours, long-lasting rains) was recorded in peat bog deposits as delivery of mineral material. The mineral layers underlying peat are typical of high-energy

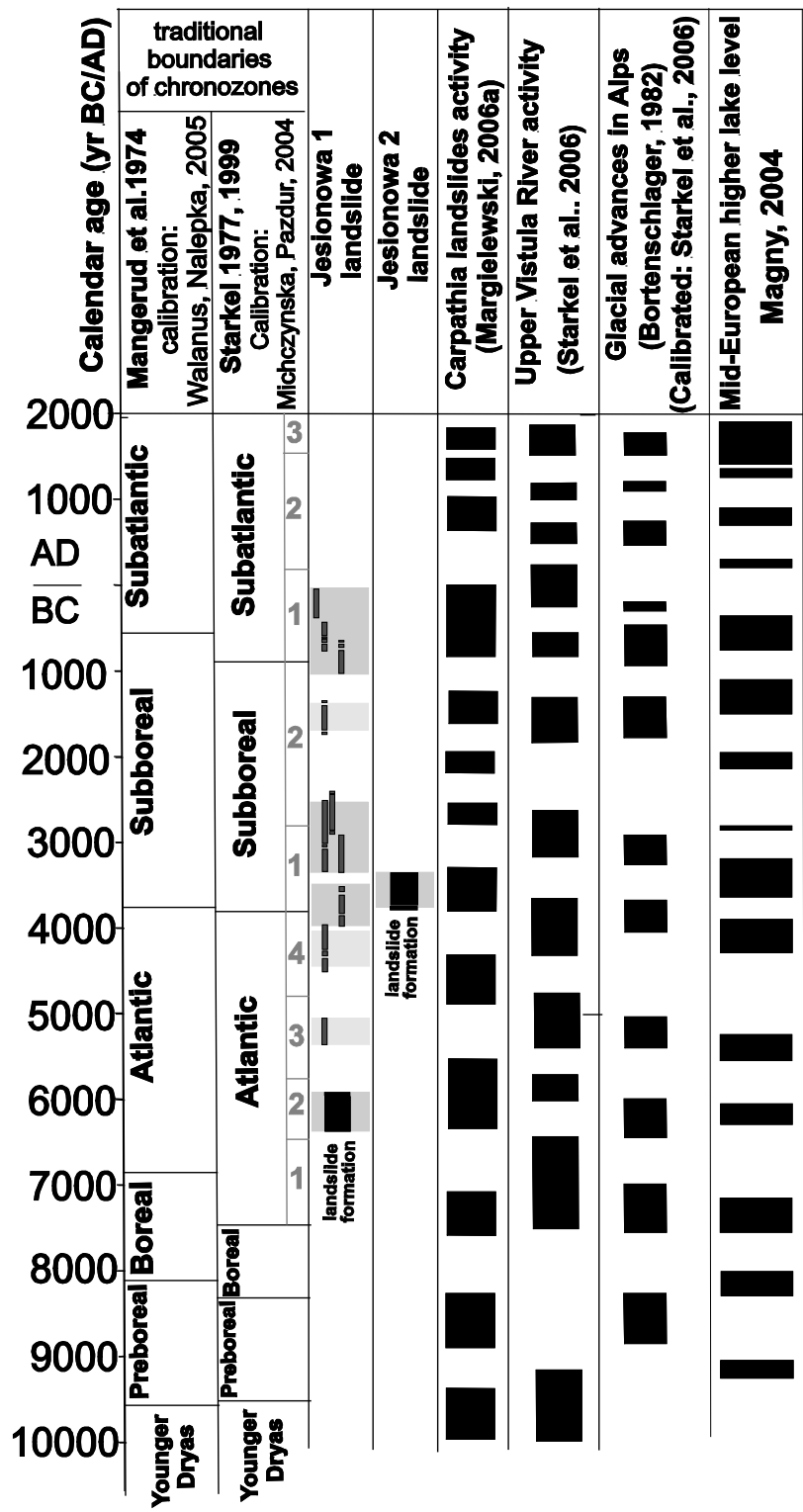

Fig. 8. Correlation of signals recorded in Jesionowa peat bog, with global climatic changes (after various authors - see at the picture).

sediments, the sand fraction predominates in these sediments (Fig. 3).

Organic accumulation (woody peat) within the depression commenced with the delay reaching about 1000 years. Its beginning was dated (GdS-1008) at 5330-5005 cal BC (Fig. 3). The delay of the peat accumulation cannot be explained by long-lasting coating of the depression bottom, enabling the formation and existence of the permanent water basin which was successively overgrown by peat-forming plants. Palynological analysis indicates that a permanent water body existed there just since the moment of the depression formation (Figs. 5 and 6). Start of the peat accumulation coincided with one of the climate humidity increase in the middle stage of the Atlantic 
Phase, during which the growth of fluvial activity of the Upper Vistula River was recorded (Starkel et al., 1996 and 2006) as well as a rise in water table in the subalpine lakes was observed (Magny, 1993 and 2004). Probably the rise in the water table in the basin could have triggered the organic material accumulation: on the palynological diagram the gradual increase in Lemna type and algae (Spirogyra t.) content is observed (Figs. $\mathbf{5}$ and 6).

The peat from the lowermost, Atlantic section of the sequence is strongly decomposed, however, the content of mineral material is relatively low (reaching ca. 30\%) (Figs. 3 and 4). This indicates limited delivery of mineral material in that time. Strong humification of peat can also suggest a relatively long-lasting drying of the peat bog after the end of the humid climate phase (Żurek and Pazdur, 1999; Żurek et al., 2002). Temporal, slight supply of mineral material to the peat bog is marked at the decline of the Atlantic Phase. Small regressions (reaching $10 \%$ ) visible on the loss on ignition curves of various logs, suggest repetition of the supplies connected with heavy rains. At that time slightly decomposed woody spruce peat was accumulated. Palynological analysis (of sporomorphs and palynomorphs) indicates a rise in the water table of the lake, caused by a strong increase in climate humidity during the transition of the Atlantic and Subboreal Phases. Relatively high frequency of duckweed (Lemna) pollen and the reed (Phragmites australis) pollen occurrence is then observed (Figs. 5 and 6). At the beginning of the Subboreal Phase intensive delivery of high-energy sediment to the basin generated formation of mineral horizon (silty clayey sand) about $0.2 \mathrm{~m}$ thick, which was dated at approx. 4315-3960 cal BC (bottom GdC-357 - see Table 1) as well as approx. 3345-3025 cal BC (middle part - GdS-990). Significant content of sand fraction in this sediment proves high intensity of the surface flow and slopewash (Fig. 4).

The rejuvenation of the lower segments of the landslide zone is related to the same climate humidity increase. At that time extensive trench with depression filled with minerogenic mire formed (Jesionowa 2 - see Figs. 1A-2 and 7). Significant climate cooling and moistening during the transition of the Atlantic and Subboreal Phases was of common character. It generated not only a significant growth of fluvial activity of the Upper Vistula River (Starkel et al., 1996 and 2006), but a water table rise in Central European lakes as well (Magny, 2004). Extreme hydrometeorological phenomena caused intensification of mass movements in the Carpathians (Alexandrowicz, 1996 and 1997; Starkel, 1997; Margielewski, 2006a; Pánek et al., 2010), Alps and Dolomites (Dapples et al., 2002; Soldati et al., 2004) as well as in the Scottish Upland (Ballantyne, 2002). In the Alps the climate cooling stimulated the advance of glaciers (Rotmoos/Piora Phase) (Bortenschlager, 1982) (Fig. 8). In the area surrounding the peat bog this cooling caused, typical for such climate changes, spruce regression which is visible on the palynological diagram (Fig. 5).
The palynological analysis indicates human activity on landslide flats during this climate cooling and moistening. It is proved by cereal pollen as well as pollen of Urtica typical of synantropic communities. Deforestation in some places is marked by a slight drop of tree pollen concentration (Figs. 5 and 6). This human activity episode (connected with the cultivation of cereals) was probably related to the colonization of the Funnel Beaker Culture, spreading over the Carpathians in that time. About $3000 \mathrm{BC}$, an intensive migration of this culture people from over-populated Małopolska Upland toward mountains took place (Kruk, 1993; Kruk and Milisauskas, 1999; Kadrow, 2001). In turn, intensive floods related to the early Subboreal increase in climate humidity, forced migration of this population to higher, dry parts of mountains (Valde-Nowak, 2001; Margielewski et al., 2010b). Flat areas of stabilized landslides, characterized by fertile soils and abounding with water were attractive places for settlement (Margielewski, 2000; 2006a; Margielewski et al., 2010b). The next delivery of allochtonous material to the peat bog producing the illuvial horizon (relative drop of loss on ignition curve reaches maximum 25\%), took place before $4030 \pm 70 \mathrm{BP}$ (approx. 2870-2345 cal BC - see Table 1) and has bipartite character (Fig. 3, logs: 1 and 2). The older episode, distinctly marked in the central $\log$ (Fig. 3, $\log 1$ ) occurred after $4.46 \mathrm{ka} \mathrm{BP}$, while the younger one took place between ages: $4230 \pm 70 \mathrm{BP}(3015-2585 \mathrm{cal} \mathrm{BC})$ and $4030 \pm 70 \mathrm{BP}$ (approx. 2870-2345 cal BC) (Fig. 3, $\log 2$ ). The palynological analysis indicates temporal water table rise of the lake during deposition of the older illuvial horizon (Fig. 6). This can prove the temporal increase in climate humidity in that time. Since the growth of fluvial activity of the Upper Vistula River was recorded about 4.5-4.1 ka BP (Starkel et al., 1996), two episodes of allochthonous material delivery to the Jesionowa peat bog can be correlated with this stage of humidity increase of the Subboreal Phase. In this period the phase of mass movement intensification was recorded in Polish Carpathians (Alexandrowicz, 1997; Margielewski, 1998, 2006a) as well as in the Alps (Dapples et al., 2002; Soldati et al., 2004). In the Tatra Mts. debris flows took place, which are recorded in the lacustrine sediments (Baumgart-Kotarba and Kotarba, 1993).

The youngest stage of mineral material delivery to the peat bog is distinctly marked on the loss on ignition curves of all logs at the depth of $0.5 \mathrm{~m}$ as drop of losses reaching $40 \%$. In various logs this supply is gradual (Fig. 3, logs 2-3) or more immediate (Fig. $3-\log 1$ ) and is finalized with deposition of thin (maximum $20 \mathrm{~cm}$ thick) mineral horizon, represented by silty sand - highenergy sediment (Fig. 4). Gradual delivery of mineral material to the peat bog is marked in one of the logs as early as the decline of the Subboreal Phase (date: $3235 \pm 75$ BP; approx.: 1730-1320 cal BC - see Table 1), however, deposition of mineral horizon took place at the beginning of the Subatlantic Phase. This is proved by 
radiocarbon age determinations of this horizon bottom, pretty consistent in every $\operatorname{logs}(2130 \pm 55 ; 2400 \pm 50$; $2680 \pm 70$ BP - Fig. 3 and Table 1), and confirmed by palynological analysis which also indicates, that at the bottom of mineral horizon a depositional gap (hiatus) occurs (Fig. 5). Moreover, this analysis confirms the existence of a water body during deposition of the mineral horizon (Fig. 6). This fact enables to state that hiatus was not a result of a lack of deposition related to the peat bog desiccation (which was usually suggested - see e.g. Żurek and Pazdur, 1999), but to erosional removal of a part of the sediments during the early Subatlantic increase in climate humidity. Such hiatuses, developed due to erosion are common in landslide peat bogs (Margielewski and Zernitskaya, 2003; Margielewski, 2006a; Margielewski et al., 2003 and 2010a).

Deposition of mineral horizon in the Jesionowa peat bog is undoubtedly connected with a particularly significant increase in climate humidity at the beginning of the Subatlantic Phase (Fig. 7) (Starkel, 1990). Climate moistening and cooling in this period caused the phase of distinct growth of fluvial activity of the Upper Vistula River recorded ca. 2350-1800 BP (Klimek, 1988; Starkel et al., 1996; Starkel, 2002). A rise in water table in subalpine lakes (Magny, 1993 and 2004) and in the northern part of Polish territory (Ralska-Jasiewiczowa, 1989) was also observed. Significant escalation of gravitational mass movements in the Carpathians (Alexandrowicz, 1996; Starkel, 1997; Margielewski, 1998 and 2006a) as well as in other mountain ranges in Europe (Ballantyne, 2002; Dapples et al., 2002; Soldati et al., 2004) is also attributed to this period. Intensive deposition of high-energy material in lakes of the Tatra Mts. was recorded, too (Baumgart-Kotarba and Kotarba, 1993). As a result of the climate cooling, the Alpine glaciers' advance was escalated (Goeschener 1 Phase - Bortenschlager, 1982; Hormes et al., 2001).

Contemporary with the beginning of the mineral horizon deposition, a particularly intensive human activity is recorded on the palynological diagram. This is marked by the appearance of continuous curves of cultivated plants, as cereals (Secale cereale) as well as synantropic plants (Plantago lanceolata, Rumex acetosa) (Fig. 5). Also charcoal, abundant in the sequence, indicates intensive human activity. Character of cultivated plants and sediments proves agricultural settlement of the Przeworsk Culture (ca. 200 cal BC-450 cal AD) commonly using the forest burnout technique for the cultivation of cereals (preferably rye Secale cereale) (Madyda-Legutko, 1996) (Figs. 3 and 6). Consequently, particularly high-energy character of sediments was influenced by both climatic and anthropogenic factors seen as evidence of burnout and intensive cultivation on the landslide flats (Margielewski, 2000 and 2006a; Margielewski et al., 2010a, b).

Regarding the occurrence of hiatus, intensive human activity could have taken place earlier, during the Celtic expansion and the La Tène Culture connected with it (Madyda-Legutko, 1996), or even with the decline of the Lusitian Culture, spread in the Carpathians between 1400-300 cal BC (Kozłowski and Kaczanowski, 1998; Valde-Nowak, 2000). Pollen of cultivated plants (Linum usitatissimum), weeds (Polygonum aviculare) and plants preferring open habitats (Rumex, Plantago lanceolata) also occurs below the hiatus (Figs. 5 and 6). This phase of human activity (which is confirmed also by other anthropopression factors - Fig. 6), could also have influenced (apart from climate) the accelerated delivery of mineral material to the peat bog. It was commenced at the declining part of the Subboreal Phase and finalized with deposition of mineral horizon (Fig. 3, log. 2).

Intensive human activity has been continued till nowadays, both during the Slavonic expansion (since the 6th century) and subsequent Valachian colonization in the Carpathians (Fig. 6).

\section{CONCLUSIONS}

In the depositional sequence of the Jesionowa landslide peat bog the records of the palaeoenvironmental changes in this part of Carpathians during the Meso- and Neoholocene has been preserved. In particular, distinct and commonly occurring climate changes (cooling and increase in humidity) at the beginning of the Subboreal and Subatlantic Phases were recorded as inserts (horizons) of mineral sediments in peat sequence, which were connected with the delivery of allochthonous material to depositional basin. During the older climate moistening the rejuvenation of the landslide zone took place, with the subsequent generation of mass movement. Within the lower parts of the landslide the trench dated at the beginning of the Subboreal Phase, was formed. Humans played an essential role in the character and distinctness of the records of depositional changes in peat sequence. Humans used this flat and water abounding area within the landslide zone since the prehistoric time: especially in the time of expansion (on the Carpathians) of the Funnel Beaker Culture (the beginning of the Subboreal Phase) and colonization of the Przeworsk Culture (approximately the beginning of the Subatlantic Phase) and/or the Valachian settlement. The climatic changes (humidity increase) during the older stage of the Subboreal Phase (4.5-4.1 ka BP) are less distinct and less uniform (different in various logs) marked in the sequence.

The pollen profile from Jesionowa presents the succession from the beginning of the Atlantic chronozone up to the modern period. The vicinity of the site in the Atlanic period was dominated by Corylus avellana thickets. About 4600-4360 cal BC spruce (Picea excelsa) expanded rapidly and displaced hazel from most of its habitats. An increase in climate humidity related to the transition between the Atlantic and the Subboreal Period, as well as to the beginning of the Subboreal Period, caused the expansion of ash (Fraxinus excelsior) in the surroundings 
of the site. The second expansion of spruce started about 3350-3020 cal BC and this species dominated in woodlands up until 2520-2040 cal BC when the fir (Abies alba) and subsequently beech (Fagus sylvatica) started to spread. Pollen spectra from the Subatlanic Period reflect strong deforestation, simultaneous with the development of pasture and agriculture.

The study conducted at the Jesionowa site proves that landslide peat bogs are sensitive indicators of palaeoenvironmental changes, both climatic and related to human activity. The research significantly expands the knowledge about the palaeoenvironmental changes in this part of the Carpathians.

\section{ACKNOWLEDGEMENTS}

The study was performed in a frame of project granted by the Ministry of Science No NN 306522738 conducted in 2010-2013. Conventional radiocarbon dating made in the Gliwice Radiocarbon Laboratory was financed by statutory funds of the Silesian University of Technology BK-2009.

\section{REFERENCES}

Alexandrowicz SW, 1996. Stages of increased mass movements in the Carpathians during the Holocene. Kwartalnik AGH Geologia 22(3): 223-262 (in Polish, English summary).

Alexandrowicz SW, 1997. Holocene dated landslides in the Polish Carpathians. In: Frenzel B, ed., Rapid mass movement as a source of climatic evidence for the Holocene. Palaeoclimate Research 19: $75-83$.

Ballantyne C, 2002. Debris flow activity in the Scottish Highlands: temporal trends and wider implications for dating. Studia Geomorphologica Carpatho-Balcanica 36: 7-27.

Battaglia S, Leoni L and Sartori F, 2003. Mineralogical and grain size composition of clays developing calanchi and biancane erosional landforms. Geomorphology 49(1-2): 153-170, DOI 10.1016/S0169-555X(02)00171-X.

Baumgart-Kotarba M and Kotarba A, 1993. Late Glacial and Holocene lacustrine sediments of the Lake Czarny Staw Gąsienicowy in the Tatra Mountains. Dokumentacja Geograficzna 4-5: 9-30 (in Polish, English summary).

Beug HJ, 2004. Leitfaden der Pollenbestimmung für Mitteleuropa und angrenzende Gebiete. Verlag Dr. Friedrich Pfeil. München: 542 pp (in German).

Birks HJB, 1979. Numerical methods for the zonation and correlation of biostratigraphical data. In: Berglund BE, ed, Palaeohydrological changes in the temperature zone in the last 15000 years. IGCP 158B. Lake and environments. Project Guide 1, Lund: 99-123.

Birks HJB, 1986. Numerical zonation, comparison and correlation of Quaternary pollen-stratigraphical data. In: Berglund BE, ed., Handbook of Holocene Palaeoecology and Palaeohydrology. J. Wiley \& Sons, Chichester: 743-774.

Bortenschlager S, 1982. Chronostratigraphic Subdivision of the Holocene in the Alps. Striae 16: 75-79.

Bronk Ramsey C, 2008. Deposition models for chronological records. Quaternary Science Reviews 27(1-2): 42-60, DOI 10.1016/j.quascirev.2007.01.019.

Bronk Ramsey C, 2009. Bayesian analysis of radiocarbon dates. Radiocarbon 51(1): 337-360.

Chrząstowski J, Nescieruk P and Wójcik A, 1995. Szczegółowa Mapa Geologiczna Polski 1: 50 000, arkusz Muszyna (Detailed Geological Map of Poland, 1:50 000, sheet Muszyna). PGI, Warszawa
Dapples F, Lotter AF, Van Leeuwen JFN, Van Der Knapp WO, Dimitriadis $\mathrm{S}$ and Oswald D, 2002. Palaeolomnological evidence for increased landslide activity due to forest clearing and land-use since $3600 \mathrm{cal} \mathrm{BP}$ in the western Swiss Alps. Journal of Palaeolimnology 27(2): 239-248, DOI 10.1023/A:1014215501407.

Dikau R, Brunsden D, Schrott L and Ibsen ML, eds., 1996. Landslide recognition. Identification, Movement and Causes. J. Wiley \& Sons: $251 \mathrm{pp}$

Ellenberg H, 1996. Vegetation Mitteleuropas mit den Alpen. UTB für Wissenschaft, Ulmer, Stuttgart 5: 1095 pp (in German).

Erdtman G, 1943. An introduction to Pollen Analysis. Chronica Botanica, Waltham, Massachussets: $230 \mathrm{pp}$.

Faegri K and Iversen J, 1989. Textbook of Pollen Analysis. Munksgaard, Copenhagen: $328 \mathrm{pp}$.

Faliński B and Pawlaczyk P, 1995. Zarys ekologii (Outline of ecology). In: Bugała, ed., Jesion wyniosty. Fraxinus excelsior L. Nasze drzewa leśne. Monografie popularnonaukowe, Sorus, PoznańKórnik 17: 157-263 (in Polish, English summary).

Folk RI and Ward WC, 1957. Brazos River bar: a study in the significance of grain size parameters. Journal Sedimentary Petrology 27(1): 3-26.

Godłowski K and Kozłowski JK, 1979. Historia starożytna ziem polskich (Ancient history of the Polish Territory). PWN Warszawa, 1168 (in Polish).

Hajdas I and Michczyński A, 2010. Age-depth model of Lake Soppensee (Switzerland) based on the high-resolution ${ }^{14} \mathrm{C}$ chronology compared with varve chronology. Radiocarbon 52(3): 1027-1040.

Hormes A, Müller B and Schlüchter C, 2001. The Alps with little ice: evidence for eight Holocene phases of reduced glacier extent in the Central Swiss Alps. The Holocene 11(3): 255-265, DOI $10.1191 / 095968301675275728$.

Heiri O, Lotter AF and Lemcke G, 2001. Loss on ignition as a method for estimating organic and carbonate content in sediments: reproducibility and comparability of results. Journal of Palaeolimnology 25(1): 101-110, DOI 10.1023/A:1008119611481.

Janczyk-Kopikowa Z, 1987. Uwagi na temat palinostratygrafii czwartorzędu (Remarks on Palynostratigraphy of the Quaternary). Kwartalnik Geologiczny 31(1): 155-162 (in Polish).

Kadłubowska JZ, 1972. Chlorophyta v. Conjugales. Zygnemaceae Zrostnicowate. In: Starmach K and Siemińska J, eds., Flora stodkowodna Polski. Kraków, PWN, 12A: 432 pp (in Polish).

Kadrow S, 2001. On a Verge of a New Epoch: Central European Society and Economy in the Early Bronze Age. Instytut Archeologii i Etnologii PAN, Kraków: 1-313 (in Polish, English summary).

Klimek K, 1988. An early Anthropohenic Alluviation in the Subcarpathian Oświęcim Basin, Poland. Bulletin of the Polish Academy of Sciences, Earth Sciences 36(2): 159-169.

Kotarba A, 1996. Sedimentation rate in the High Tatra Lakes during the Holocene - geomorphic interpretation. Studia Geomorphologica Carpatho-Balcanica 30: 51-56.

Kozłowski JK and Kaczanowski P, 1998. Najdawniejsze dzieje ziem polskich (Earliest history of Polish terrotory). Wyd. Fogra, Kraków: 1-382 (in Polish).

Kruk J, 1993. Rozwój społeczno-gospodarczy i zmiany środowiska przyrodniczego wyżyn lessowych w neolicie (4800-3800 BC) (Social-economical development and changes of natural environment of the loess Uplands during the Neolithic 4800-3800 BC). Sprawozdania Archeologiczne 45: 7-17 (in Polish).

Kruk J and Milisauskas S, 1999. The Rise and Fall of Neolithic Societies Instytut Archeologii $i$ Etnologii PAN, Kraków: 1-403 (in Polish with English summary).

Madyda-Legutko R, 1996. Zróżnicowanie kulturowe polskiej strefy beskidzkiej $w$ okresie lateńskim i rzymskim (Cultural diversity of Polish Beskidy Zone during La Tene and Roman Periods). Wydawnictwa Uniwersytetu Jagiellońskiego, Kraków: 166 pp. (in Polish, German summary).

Magny M, 1993. Holocene fluctuation of lake levels in the French Jura and sub-Alpine ranges, and their implications for past general circulation pattern. The Holocene 3(4): 306-313, DOI $10.1177 / 095968369300300402$. 
Magny M, 2004. Holocene climatic variability as reflected by mid European lake-level fluctuation and its probable impact on prehistoric human settlements. Quaternary International 113(1): 65-79, DOI 10.1016/S1040-6182(03)00080-6.

Makra L, Juhász M, Béczi R and Borsos E, 2005. The history and impacts of airborne Ambrosia (Asteraceae) pollen in Hungary. Grana 44: 57-64, DOI 10.1080/00173130510010558.

Mangerud J, Andersen ST, Berglund BE and Donner J, 1974. Quaternary stratigraphy of Norden, a proposal for terminology and classification. Boreas 3(3):109-126, DOI 10.1111/j.15023885.1974.tb00669.x.

Margielewski W, 1997a. Dated landslides of the Jaworzyna Krynicka Range (Polish Outer Carpathians) and their relation to climatic phases of the Holocene. Annales Societatis Geologorum Poloniae 67: 83-92.

Margielewski W, 1997b. Landslide forms of the Jaworzyna Krynicka Range and their connection with the geological structure of the region. Kwartalnik AGH, Geologia 23(1): 45-102 (in Polish, English summary)

Margielewski W, 1998. Landslide phases in the Polish Outer Carpathians and their relation to climatic changes in the Late Glacial and the Holocene. Quaternary Studies in Poland 15: 37-53.

Margielewski W, 2000. Economical role of the landslides in the Beskid Makowski Mts. Problemy Zagospodarowania Ziem Górskich 46: 15-34 (in Polish, English summary).

Margielewski W, 2006a. Records of the Late Glacial-Holocene palaeoenvironmental changes in landslide forms and deposits of the Beskid Makowski and Beskid Wyspowy Mts. area (Polish Outer Carpathians). Folia Quaternaria 76: 1-149.

Margielewski W, 2006b. Structural control and types of movements of rock mass in anisotropic rocks: case studies in the Polish Flysch Carpathians. Geomorphology 77(1-2): 47-68, DOI 10.1016/j.geomorph.2006.01.003.

Margielewski W and Zernitskaya V, 2003. Late Glacial-Holocene palaeoenvironmental evidence recorded in the Hajduki peat bog (Beskid Sredni Mts, Outer Western Carpathians). Folia Quaternaria 74: 57-73.

Margielewski W, Obidowicz A and Pelc S, 2003. Late Glacial Holocene peat bog on Kotoń Mt. and its significance for reconstruction of palaeoenvironment in the Western Carpathians (the Beskid Makowski Range, South Poland). Folia Quaternaria 74: 35-56.

Margielewski W, Michczyński A, Obidowicz A, 2010a. Records of the middle and late Holocene palaeoenvironmental changes in the Pcim-Sucha landslide peat bogs (Beskid Makowski Mts., Polish Outer Carpathians). Geochronometria 35: 11-23, DOI 10.2478/v10003-010-0009-1.

Margielewski W, Krapiec M, Valde-Nowak P and Zernitskaya V, 2010b. A Neolithic yew bow in the Polish Carpathians. Evidence of the impact of human activity on mountainous palaeoenvironment from the Kamiennik landslide peat bog. Catena 80(1): 141153, DOI 10.1016/j.catena.2009.11.001.

Michczyńska DJ and Pazdur A, 2004. Shape Analysis of Cumulative Probabilisty Density Function of Radiocarbon Dates Set in the Study of Climate Change in the Late Glacial and Holocene. Radiocarbon 46: 733-744.

Michczyński A, 2011 (in press). Chronologie bezwzględne na podstawie datowania radioweglowego (Absolute chronologies constructed on the basis of radiocarbon dating). (in Polish).

Mycielska-Dowgiałło E and Rutkowski J, eds., 1995. Researches of Quaternary sediments. Some methods and interpretation of the results. Warszawa, Wydział Geografii i Studiów Regionalnych UW: 356 pp. (in Polish).

Nalepka D and Walanus A, 2003. Data processing in pollen analysis. Acta Palaeobotanica 43(1): 125-134.

Oberdorfer E, 1990. Pflanzensoziologiche Exkursionsflora. 6th ed. Verlag Eugen Ulmer, Stuttgart: 1050 pp (in German).

Obidowicz A and Margielewski W, 2008. Problematyka klasyfikacji torfowisk górskich (Problems of mountainous peat bogs classification). In: Żurek S, ed., Torfowiska gór i Wyżyn. Uniwersytet im. J. Kochanowskiego, Kielce:103-109 (in Polish).
Page CN, 1986. The strategies of bracken as a permanent ecological opportunist. In: Smith RT and Taylor JA, eds., Bracken, ecology, land use and control technology, 1985 July 1- July 5, The Parthenon Publishing Group Limited, Leeds, England, Lancs: 173-181.

Pánek T, Hradecký J, Smolková V, Šilhán K, Minár J and Zernitskaya $\mathrm{V}, 2010$. The largest prehistoric landslide in northwestern Slovakia: Chronological constrains of the Kykula long-runout landslide and related dammed lakes. Geomorphology 120(3-4): 233247, DOI 10.1016/j.geomorph.2010.03.033.

Pettijohn FJ, 1975. Sedimentary Rocks. 3rd ed. New York, Harper and Row: $628 \mathrm{pp}$

Pietrzak M, 2002. The impact of land-use change on ground relief in the Wiśnickie Foothills, Southern Poland. In: Przemiany środowiska na Pogórzu Karpackim, vol. 2. Instytut Geografii i Gospodarki Przestrzennej, Uniwersytet Jagielloński, Kraków: 1-149 (in Polish, English summary)

Pohl F, 1937. Die Pollenerzeugung der Windblütter. Beihefte des Botanischen Centralblattes 55A: 365-471 (in German).

Ralska-Jasiewiczowa M, ed., 1989. Environmental changes recorded in lakes and mires of Poland during the last 13000 years, Part III. $A c$ ta Palaeobotanica 29: 1-120.

Reille M, 1992. Pollen et spores d'Europe et d'Afrique du Nord. Laboratoire de Botanique Historique et Palynologie, Marseille: 543 pp (in French)

Reimer PJ, Baillie MGL, Bard E, Bayliss A, Beck JW, Blackwell PG, Bronk Ramsey C, Buck CE, Burr GS, Edwards RL, Friedrich M, Grootes PM, Guilderson TP, Hajdas I, Heaton TJ, Hogg AG, Hughen KA, Kaiser KF, Kromer B, McCormac FG, Manning SW, Reimer RW, Richards DA, Southon JR, Talamo S, Turney CSM, van der Plicht $\mathrm{J}$ and Weyhenmeyer CE, 2009. IntCa109 and Marine09 radiocarbon age calibration curves, 0-50,000 years cal BP. Radiocarbon 51(4): 1111-1150.

Soldati M, Corsini A and Pasuto A, 2004. Landslides and climate change in the Italian Dolomites since the Late Glacial. Catena 55(2): 141-161, DOI 10.1016/S0341-8162(03)00113-9.

Starkel L, 1977. Palaeogeografia holocenu (Holocene's palaeogeography). PWN Warszawa, pp. 1-362 (in Polish)

Starkel L, 1988. Man's activity as a cause of changes of denudation and sedimentation processes in the Holocene. Przeglad Geograficzny 60: 251-265 (in Polish, English summary).

Starkel L, 1989. The evolution of natural environment of Carpathian Mts. During the human management. Problemy Zagospodarowania Ziem Górskich 29: 35-45.

Starkel L, 1990. Holocene as interglacial- problems of stratigraphy. Przeglad Geologiczny 38: 13-16 (in Polish, English summary).

Starkel L, 1997. Mass movement during the Holocene: Carpathian example and the European perspective. In: Frenzel B, ed., Rapid mass movement as a source of climatic evidence for the Holocene. Palaeoclimate Research 19: 385-400.

Starkel L, 1999. Chronostratigraphy of Late Vistulian and Holocene in Poland. In: Pazdur A, Bluszcz A, Stankowski A and Starkel L, eds., Geochronologia górnego czwartorzędu Polski, w świetle datowania radioweglowego i luminescencyjnego, WIND, Wrocław: 280-283 (in Polish).

Starkel L, 2002. Change in the frequency of extreme events as the indicator of climate change in the Holocene (in fluvial systems). Quaternary International 91(1): 25-32, DOI 10.1016/S10406182(01)00099-4.

Starkel L, Kalicki T, Krąpiec M, Soja R, Gębica P and Czyżowska E, 1996. Hydrological changes of valley floor in the Upper Vistula Basin during Late Vistulian and Holocene. In: Starkel L, ed., Evolution of the Vistula river Valley during the last 15000 years, $p$. IV, Geographical Studies Special Issue 9: 1-128.

Starkel L, Soja R and Michczyńska DJ, 2006. Past hydrological events reflected in Holocene history of Polish Rivers. Catena 66(1-2): 2433, DOI 10.1016/j.catena.2005.07.008.

Stockmarr J, 1971. Tabletes with spores used in absolute pollen analysis. Pollen et Spores 13(4): 615-621.

Tobolski K and Nalepka D, 2004. Fraxinus excelsior L. - Ash. In: Ralska-Jasiewiczowa M, Latałowa M, Wasylikowa K, Tobolski K, Madeyska E, Wright HE, Jr and Turner C, eds., Late Glacial and 
Holocene history of vegetation in Poland based on isopollen maps. W. Szafer Institute of Botany, Polish Academy of Sciences, Kraków: 105-110.

Toney JL and Anderson RS, 2006. A postglacial palaeoecological record from the San Juan Mountains of Colorado USA: fire, climate and vegetation history. The Holocene 16(4): 505-517, DOI 10.1191/0959683606h1946rp.

Valde-Nowak P, 1988. Etapy $i$ strefy zasiedlania Karpat polskich $w$ neolicie i na poczatku epoki brazu (Stages of colonisation of the Polish Carpathians in the Neolithic and Early Bronze eppochs). Zakład Narodowy im. Ossolińskich, Wrocław (in Polish).

Valde-Nowak P, 2000. Dzieje osadnictwa (History of settlement) In: Staszkiewicz J, Alexandrowicz Z, Wieczorek T and Witkowski Z, eds., Przyroda Popradzkiego Parku Krajobrazowego: 81-90. Popradzki Park Krajobrazowy Publ. Stary Sącz 2000. (in Polish)

Valde-Nowak P, 2001. Etapy i strefy w badaniach nad neolitem w polskich Karpatach (Stages and Zonation of researches of Neolithic of the Polish Carpathians). In: Gancarski J, ed., Neolit i poczatki epoki brązu w Karpatach Polskich, Krosno: 89-106.

Van Geel B, 1978. A palaeoecological study of Holocene peat bog section in Germany and The Netherlands, based on the analysis of pollen, spores and macro- and microscopic remains of fungi, algae, coprophytes and animals. Review Palaeobotany and Palynology 25(1): 1-120, DOI 10.1016/0034-6667(78)90040-4.

Van Geel B, 2001. Non-pollen palynomorphs. In: Smol JP, Birks HJB and Last WM, eds., Tracking Environmental Change Using Lake Sediments, Volume 3: Terrestrial, Algal and Siliceous Indicators. Kluver Academic Publishers, Dordrecht, The Netherlands: 99-119.

Van Geel B, Bohnecke SJP and Dee H, 1980. A palaeoecological study of an upper Late Glacial and Holocene sequence from "De Borchert", The Netherlands. Review Palaeobotany and Palynology 31: 367-448, DOI 10.1016/0034-6667(80)90035-4.
Van Geel B and Andersen ST, 1988. Fossil ascospores of the parasitic fungus Ustulina deusta in Eemian deposits in Denmark. ReviewPalaeobotany and Palynology 56(1-2): 89-93, DOI 10.1016/00346667(88)90076-0.

Van Geel B, Buurman J, Brinkkemper O, Schelvis J, Aptroot A, Van Reenen G and Hakbijl T, 2003. Environmental reconstruction of a Roman Period settlement site in Utigeest (The Netherlands), with special reference to coprophilous fungi. Journal of Archaeological Science 30(7): 873-883, DOI 10.1016/S0305-4403(02)00265-0.

Van Geel B, Zazula GD and Schweger CE, 2007. Spores of coprophilous fungi from under the Dawson tephra (25,300 14C years BP), Yukon Territory, northwestern Canada. Palaeogeography, Palaeoclimatology, Palaeoecology 252(3-4): 481-485, DOI 10.1016/j.palaeo.2007.04.017.

Walanus A and Nalepka D, 1999. POLPAL. Program for counting pollen grains, diagrams plotting and numerical analysis. Acta Palaeobotanica, Suppl. 2: 659-661

Walanus A and Nalepka D, 2005. The calendar age of boundaries arbitrarily determined on the radiocarbon timescale. Botanical Guidebooks 28: 313-321 (in Polish, English summary).

Wentworth CK, 1922. A scale of grade and class terms for clastic sediments. Journal of Geology 30: 377-392.

Żurek S and Pazdur A, 1999. Zapis zmian palaeohydrologicznych w rozwoju torfowisk Polski (Records of palaeohydrological changes in peat bogs of Polish Territory). In: Pazdur A, Bluszcz A, Stankowski A and Starkel L, eds., Geochronologia górnego czwartorzędu Polski, w świetle datowania radiowęglowego i luminescencyjnego, WIND, Wrocław: 215-228 (in Polish).

Żurek S, Michczyńska D, Pazdur A, 2002. Time record of palaeohydrological changes in the development of mires during the Late Glacial and Holocene, North Podlasie and Holy Cross Mts. Geochronometria 21: 109-118. 